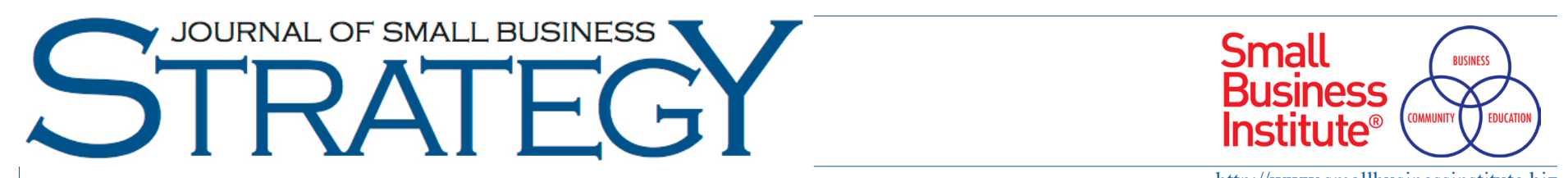

http://www.smallbusinessinstitute.biz

\title{
The effect of marketing mix perception on the intention of online merchant financing
}

\author{
Fermico Karambut
}

Indonesia Banking School, Jl. Kemang Raya No.35, Kebayoran Baru, Jakarta Selatan 12730, Indonesia, fermico.karambut@ibs.ac.id

www.jsbs.org

Keywords:

E-marketplace, Intention, Microcredit, Marketing mix, Online merchant

\section{A B S T R A C T}

With a large number of Micro, Small, and Medium Enterprises (MSMEs), Indonesia has an opportunity to pioneer the development of new digital services, especially advanced mobile financial service and e-commerce. Therefore, the government recommended e-marketplaces as a channel to provide micro-financing MSME registered as an online merchant. Financial Institutions are more secure in offering credit facilities to merchants in e-marketplaces because it is easier to verify borrower status and transaction records. This paper aimed to examine the role of the marketing mix (product, price, place, and promotion) perceived in submitting microcredit's online application. Research on the intention of online merchants in e-marketplaces used the modified Decomposed Theory of Planned Behavior (DTPB) model approach. Data were collected from Indonesian online seller associations using a convenience sampling approach, and the research hypotheses were tested by applying structural equation modeling. The results showed that besides having a significant effect on online financing intention, the marketing mix's perception could also be developed by mediating subjective norms.

\section{Introduction}

Micro, Small, and Medium Enterprises (MSMEs) are the backbone of the national economy. However, Indonesia MSMEs are typically unable to access capital to invest in business development and increase their business potential (Capri, 2018). About $60-70 \%$ of MSMEs do not have access to bank financing because there are no assets used as collaterals (Bank Indonesia, 2015; ING Bank, 2016). Most micro-merchants save money at home because it is comfortable and practical to immediately use for business or personal purposes (Pulse Lab Jakarta, 2018). Lack of access to basic funding remains a major challenge for MSMEs in Indonesia (Capri, 2018). Therefore, in 2007, the Government launched a microcredit scheme named Kredit Usaha Rakyat (KUR) to open financing access to un-bankable MSMEs (Indonesian Government, 2015). To attract financial institutions to participate in financing programs, the government plans to channel KUR through e-commerce (Indonesian Government, 2017). Microcredit channel through e-commerce is considered safer for financial institutions because the borrower and his business are verified. The borrower is more flexible because the application is easy and practical.

The e-marketplace platform provides facilities to

Journal of Small Business Strategy

2021, Vol. 31, No. 03, 19-32

ISSN: 1081-8510 (Print) 2380-1751 (Online)

(C) Copyright 2021 Small Business Institute ${ }^{\circledR}$ submit the credit application. With this feature, online merchants can apply for working capital loans to financial institutions such as banks, leasing (finance companies), and technology finance (peer to peer lending) companies. Financial institutions have to register to become an e-marketplace partner to display their credit products on the platform sites. Examples of online marketplaces in Indonesia that show microcredit facilities include Tokopedia (https:// www.tokopedia.com), Bukalapak (https://www.Bukalapak. com), Lazada (https://pages.lazada.co.id), and Matahari Mall (https://super.mataharimall.com). Prospective borrowers who registered as online merchants have verified names, addresses, and product types. Financers can analyze transaction turnover at any time since the system recorded all the transactions (Karambut et al., 2019).

Investigating online financing intention is essential to help the financial institution identify the factors affecting online financing intention and predict the impact of the marketing mix perception on e-marketplace merchant intention. To maximize the effectiveness of sales and attract more customers, marketing mix elements, which are generally known today as the 4Ps, play a significant role in the financial and banking sector to create awareness regarding their services to the public (Ennew \& Waite, 2007; Kotler \& Armstrong, 2012; McCarthy, 1960). Pogorelova et al. (2016) identified a change in the marketing mix elements in e-commerce following e-business trends and internet technology. Previous researches had shown that these variables

APA Citation Information: Karambut, F. (2021). The effect of marketing mix perception on the intention of online merchant financing. Journal of Small Business Strategy, 31(3), 19-32. 
have a good relationship with online purchase intention. In terms of relationships, product, price, promotion, and place (distribution) offer a positive and moderate relationship with online purchase intention (Baltes, 2016; Sulaiman et al., 2017).

For the multi-sided platform (MSP) firms with Business-to-business (B2B) or Business-to-consumer (B2C) business models, their open innovation practice commonly starts with the inbound process. For instance, SME sellers provide inbound new products/services to the platform, third-party logistics provides the solution to innovate the fulfillment process (Santoso et al., 2020), and financial institutions offer online credit facilities (Karambut et al., 2019). Service quality was a crucial indicator for increasing browsers and sales amount (Wang \& Kim, 2018). Research using e-commerce data and financial institution data is generally only used for internal purposes. So far, there has been no analysis that measures how effective it is to offer microcredit to merchants through e-commerce. Hence, even though credit facilities through e-commerce have been available since 2014, there has never been any published data to show credit distribution's success rate. This research is the first to conduct a large-scale empirical investigation to measure marketing mix activity's effectiveness through e-marketplaces media.

The exploratory study aimed to scrutinize the online merchants' intention model in applying for microcredit as an initial step in financial institutions' marketing strategy. Taylor and Todd (1995) indicated that a better understanding of the relationships between the belief structures and antecedents of intention requires the decomposition of attitudinal beliefs. This research used a model approach of the Decomposed Theory of Planned Behavior (Decomposed TPB), modified with marketing mix variables. We considered both direct and indirect effects of marketing mix perception to understanding the online merchants' intention model. The empirical findings provided the marketing mix matrix for managerial implication as initial information for the financial institution.

\section{Literature Review}

According to the American Marketing Association (AMA), the definition of marketing cited by Kotler and Keller (2016) is an organizational function and a series of processes for creating, communicating, delivering, and providing added value to customers, partners, and other broader parties. The marketing mix is the set of controllable variables that the firm can use to influence buyers' responses (Kotler \& Keller, 2016). The marketing mix regarding Kotler and Armstrong's (2012) definition, is a tactical mar- keting tool, including product, price, promotion, and place (distribution) combined by the company to produce the desired response in the target market. The rise of e-commerce has remarkably altered the product element of the marketing mix. When marketing experts developed the marketing mix in the 1960s, commerce did not use the Internet or technology (McCarthy, 1960). The e-marketing mix, namely e-product, price intelligence (price sensitivity), delivery risk (place), and promotional intelligence, influences consumer buying-decisions in online markets (Sriram et al., 2019).

In the original definition, products mean physical goods or services. According to Kannan and Li (2017), digital technologies changed the products in three ways. First, they combine actual products with digital services. Second, digital technologies make it possible for products to the network, which releases the products' inner value. Third, they transform products into digital services. The price is defined as the money that customers exchange in terms of services or products, or the value they receive (Kotler \& Armstrong, 2012). Price discrimination has become popular since pricing is described as dynamic (Hussein \& Attia, 2019; Ighomereho \& Iriobe, 2019; McCarthy, 1960). Placewise, the purchase is no longer connected to a physical place as shopping is possible $24 / 7$ in online stores (Heikkinen, 2018). Promotion focuses more on the effectiveness of such new media and its incremental contribution over traditional media in building brands and affecting outcome variables of interest, not only online and mobile but also sub-channels within each of these environments such as social channels, search engines, and e-mail (Kannan \& Li, 2017).

Marketplaces are the solution to current and future e-commerce demands. An electronic marketplace is a virtual, online space on which buyers and sellers meet to carry out transactions involving goods or services (Corrot \& Nussenbaum, 2014). Capri (2018) described e-commerce as all transactions made in the digital space on platforms that connect buyers, sellers, and other service providers. McKinsey \& Company (2018) estimated that there were about 30 million online shoppers in Indonesia. Around $40 \%$ of e-commerce sales in Indonesia are estimated to conduct through B2C/B2B e-commerce sites (business-to-consum$\mathrm{er} /$ business-to-business), $30 \%$ sales through $\mathrm{C} 2 \mathrm{C}$ sites (consumer-to-consumer), and the remaining $30 \%$ through social media, blog stores, and messaging applications (Hoppe et al., 2016).

The intention of conducting e-commerce transactions or purchases s defined as buyers' intention to exchange through shopping sites, such as sharing information, maintaining business relationships, and making business transactions (Dachyar \& Banjarnahor, 2017). Creating the technological infrastructure around these online frameworks has 
revealed a shortage of resources, including a lack of service in Indonesian financial institutions (Capri, 2018). According to the Regulation of the Coordinating Minister for the economy, the definition of microcredit is credit/financing of working capital or investment to individual borrowers/ individuals, business entities, and business groups that are productive and feasible but do not yet have collateral (Indonesian Government, 2015). Regarding ING Bank's (2016) definition, Micro, Small, and Medium Enterprises (MSMEs) financing can simply be described as providing money to a micro-entrepreneur now based on their commitment to repay at a later date. Small business loan availability may help small firms have a greater survival rate by allowing them to pursue their strategies (Galli-Debicella, 2020)

Many researchers and practitioners have attempted to explain and introduce a theoretical perspective for a user's acceptance and adoption of ICT (Information Communication Technology). Intentional theories previously used, for instance, are the Theory of Reasoned Action (TRA) (Fishbein \& Ajzen, 1975), Theory of Planned Behavior (TPB) (Ajzen, 1991), Technology Acceptance Model (TAM) (Davis, 1989), and the Decomposed TPB (Taylor \& Todd, 1995). Based on Taylor and Todd's examination, the Decomposed TPB model has better explanatory power for behavioral intention, attitude, and subjective norm than the TRA and pure TPB models. Decomposed TPB is an excellent model to predict IT usage behavior by decomposing the belief structure and adding several TAM related factors (Momani \& Jamous, 2017; Lai, 2017).

\section{Hypotheses}

Attitude, according to Ajzen, is the psychological tendency expressed through favorable or unfavorable evaluation of a particular entity (Ajzen, 1991). In general, the more favorable a person's attitude is towards individual behavior, the more likely it is that the person will want to engage in the behavior. Research has shown that attitude directly influences online shopping intention was conducted by Ye and Zhang (2014) on online buyers in e-marketplace Taboo.com in China and by Bahrun et al. (2015) on students in Malaysia. Based on the previous Technology Acceptance Model (TAM) researches, perceived ease of use caused a positive influence on perceived usefulness. Both perceived usefulness and perceived ease of use caused a positive impact on attitudes (Al-Mamary et al., 2016; Davis, 1989). In the context of e-commerce, definition of perceived usefulness (PU) is the degree to which a customer believes that engaging in online shopping will improve his effectiveness (Baharun et al., 2015; Changchit et al., 2018). Perceived ease of use (PEU), defined as purchasing a product online, would be free of effort (Gangwal \& Bansal, 2016; Reynolds et al., 2020; Ye \& Zhang, 2014). Marketing mix activities influenced attitude, referring to the findings of Mosavi's research (2012) related to online shopping and Mbengo and Phiri's study (2015) regarding bank selection. As stated earlier, the e-marketplace platform's mechanism is a medium of online transactions between online buyers, and online sellers are the same as a medium for credit applying between online sellers (merchants) and financial institutions. Based on previous observations, here are the proposed hypotheses:

H1a. Attitude Behavior (AB) influences the intention of online merchant financing (IOMF).

H1b. Perceived Ease of Use (PEU) influences the attitude toward behavior $(\mathrm{AB})$.

H1c. Perceived Usefulness (PU) influences the attitude toward behavior $(\mathrm{AB})$.

H1d. Marketing Mix (MM) Mix influences the attitude toward behavior $(\mathrm{AB})$.

Subjective Norm (SN) terminology is the perceived social pressure to perform or not to perform the behavior. It suggests that people have certain expectations regarding their significant others' perceptions of their engaging in the behavior in question (Ajzen, 1991). The following studies by Taylor and Todd (1995) found that both internal (family/ household) and external (friends/neighbors) normative beliefs significantly influence subjective norms. Aziz and Afaq (2018) and Maulana et al. (2018) have undertaken a study of intention to adopt Islamic banking that has taken place in Indonesia and Pakistan, respectively. The studies conducted in financial services have shown the validity of normative belief and subjective norms on the intention. Research by Aziz et al. (2017) and Husin and Rahman (2015) also prove that information/marketing mix through mass media influences subjective norms in the family takaful scheme. Therefore, the hypotheses proposed in this research:

H2a. Subjective Norm (SN) influences the intention of online merchant financing (IOMF).

H2b. Normative Belief (NB) influences the subjective Norm (SN).

H2c. Marketing Mix (MM) influences the subjective norm (SN).

Perceived Behavioral Control (PBC) refers to a person's perceptions of the ease or difficulty of performing a particular behavior. In other words, an individual's confidence in achieving a specific task significantly influences 
intention and behavior (Ajzen, 1991). Studies conducted in mobile banking have shown the validity of PBC on the intention to adopt certain services. Gangwal and Bansal (2016) and Kazemi et al. (2013) have undertaken a study that has taken place in India and Iran, respectively. Decomposed PBC into three constructs: self-efficacy, resources facilitating condition, and technology facilitating condition (Taylor \& Todd, 1995). However, this study only adapted two of the constructs; self-efficacy and resources that were enabling conditions, as founded by Kazemi et al. (2013) in research on mobile banking adoption intentions in Ishafan, Iran. In a study on the intention to choose a vehicle, perceived behavior control is also influenced by the social marketing mix, as examined by Dolatabadi et al. (2013), and digital marketing, as investigated by Dahiya and Gayatri (2017). Thus, this study postulated the following hypotheses:

H3a. Perceived Behavioral Control (PBC) influences the Intention of Online Merchant Financing (IOMF).

H3b. Self-Efficacy (SE) influences Perceived Behavioral Control (PBC).

H3c. Facilitating Condition (FC) influences Perceived Behavioral Control (PBC) .

H3d. Marketing Mix (MM) influences Perceived Behavioral Control (PBC).

In financial services, the marketing mix must recognize and respond to the distinctive features of service prod- ucts. In particular, when managing the elements of product, price, promotion, and place, marketers in the financial services sector need to pay specific attention to the people delivering the service, the process of the service, and the physical evidence which represents the service (Ennew \& Waite, 2007). Research by Pour et al. (2013) in Saderat Bank (Kermanshah provinces, Iran) and Aqrobaee et al. (2014) in Mehr Eqtesad Bank (Isfahan provinces, Iran) proved that the marketing mix variables have a significant positive effect in attracting customers. Hartoyo et al. (2019) argued that online seller perception of the marketing mix was statistically significant with the intention to apply for microcredit through e-commerce platforms in Indonesia. Thus, the following Hypothesis needs to be substantiated:

H4. Marketing Mix (MM) influences the Intention of Online Merchant Financing (IOMF).

Previous studies of the determinant of intention to apply for the credit generally use the Theory of Planned Behavior (TPB) model as a theoretical basis. With control ability of required resources by users, TPB variables mostly focus on users' traits or subjective awareness but do not have specific suggestions on the marketing of technology products. This study tried to confirm the effect of the marketing mix (MM) on the intention of online merchant financing (IOMF) toward the e-marketplace platform using the modified Decomposed Theory of Planned Behavior Model (DTPB). Based on a study of previous research, a conceptual model of research can effectively elicit marketing mix perception directly or indirectly through the construct of attitude toward behavior ( $\mathrm{AB})$, subjective norms $(\mathrm{SN})$, and behavioral control (PBC), as presented in Figure 1.

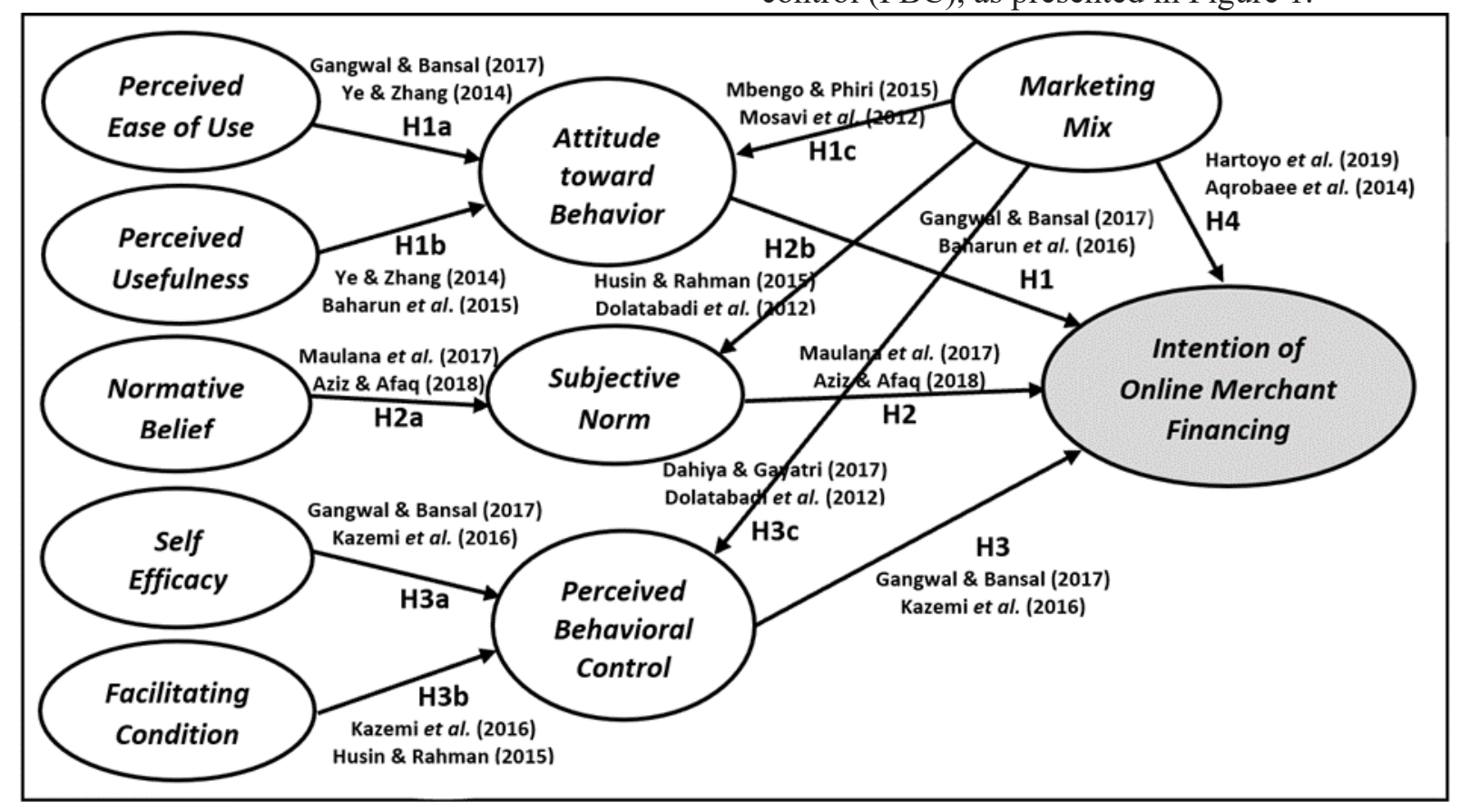

Figure 1. The Conceptual Research Model 


\section{Method}

The type of this paper used quantitative research with designs and techniques from the explanatory approach. We used survey sampling through an online interview to minimize the questionnaire's misinterpretation. We conducted an online interview with members of the Indonesian Online Sellers Association (APOI) with criteria that have run an online business at e-marketplace sites for at least six months. APOI is a non-profit organization that aims to help MSME entrepreneurs develop their business online. APOI was founded in 2008 and has members spread across 11 major cities in Indonesia. The survey collected 456 respondents or $46.20 \%$ of 987 APOI members who fulfilled the criteria and successfully contacted. After excluding incomplete and questionable responses, 235 sets of data were used for analysis.

The developed questionnaire consists of 32 items of questions as indicators of 10 research constructs: perceived ease of use (PEOU), perceived usefulness (PU), attitude toward behavior $(\mathrm{AB})$, normative belief $(\mathrm{NB})$, subjective norm (SN), self-efficacy (SE), facilitating condition (FC), perceived behavior control (PBC), marketing mix (MM) and intention of online merchant financing (IOMF). The study used five points Likert type scale, where the lowest was Strongly Disagree $=1$ and the highest Strongly Agree $(\mathrm{SS})=5$. The method technique used purposive sampling and analyzed by software Linear Structural Relationship (LISREL) version 8.80 software to describe the Structural Equation Model (SEM). SEM can calculate and explain the relationship between exogenous latent variables on endogenous latent variables to examine the causal effect's influence, based on Confirmatory Factor Analysis (CFA).

Furthermore, this study provides novelty on managerial implications by building a marketing mix matrix based on research findings. Nine senior managers of financial institutions as practical expert were interviewed with the Focus Group Discussion (FGD) method to discuss the research objectives (Marczak \& Sewell, 2006). Participants responses were provided on the matrix to confirm the effect of the research findings on marketing strategy

\section{Respondent Demographics}

The demographics of online seller respondents in this study were the majority of those under the age of 37 years $(70.21 \%)$, male sex $(72.77 \%)$, bachelor graduation (51.91\%), married (73.19\%), Javanese (37.87\%), Muslim (71.49\%) and still have status as an employee or received a salary $(42.98 \%)$. Regarding the characteristics of online sellers, the majority of respondents have already run the business for more than two years $(85.11 \%)$, dominated by distributors/resellers $(83.40 \%)$, already had a credit facility at a financial institution (53.62\%), had experiences in applying for credit online (53.62\%), made online transactions $>30$ times per month $(60.43 \%)$, had a transaction value $<1$ million rupiahs $(74.89 \%)$ and had a monthly working capital needs of $<25$ million rupiahs.

\section{Structural Model Analysis}

The Structural Equation Model (SEM) with an application of Linear Structural Relationship (LISREL) version 8.80 was used to test the conceptual model and its hypotheses. According to Hartoyo et al. (2019), a reflective measurement model should be evaluated by interpreting their reliability and validity before performing an SEM.

\section{Results}

\section{Validity Test}

The first testing stage was to test the validity or match test of the measurement model between latent variables and indicators. A variable has a good valid test for the construct or latent variable if its standardized loading factor (SLF) $\geq$ 0.50 and $t$-value $\geq 1.96$. Based on Table 1 , only 27 indicators were declared valid or explained the latent variables measured in the study (SLF at 0,5 or greater).

\section{Reliability Test}

The method used in the reliability test is the split-half method with the Cronbach Alpha formula. The set minimum threshold for establishing reliability is $\geq 0.60$, while the set threshold for composite reliability is $\geq 0.70$. Regarding Table 2, in this study the Cronbach's Alpha values ranged from 0.73 to 0.93 , representing relatively higher internal consistency among the questionnaire items.

\section{Structural Model Test}

Based on the results of testing the structural model, the intention of credit online (ICO) only has a relationship or is significantly influenced by attitude (AB), subjective norms $(\mathrm{SN})$, and marketing mix (MM) where t-count $>$ of t-table are 1.96. The indirect path of the marketing mix (MM) to intention through attitude $(\mathrm{AB})$ and behavior control $(\mathrm{PBC})$ were not significant since the marketing $\operatorname{mix}(\mathrm{MM})$ does not affect attitudes (AT). In contrast, behavior control (PBC) does not affect intention. Table 3 below shows the results of the structural model testing of the 11 paths of relationships between latent variables in this study. 
Table 1

The result of the validity test of latent variable indicators

\begin{tabular}{|c|c|c|c|c|}
\hline Codes & Latent Variable Indicators & SLF* & $t$-value & Remarks \\
\hline \multicolumn{5}{|c|}{ PEU (Perceived Ease of Use) } \\
\hline PEU1 & The flow process of online financing is easy to trace & 0.69 & 9.41 & Valid \\
\hline PEU2 & Online financing application is easy to learn & 0.77 & 7.87 & Valid \\
\hline PEU3 & Online financing requirement is easy to fulfill & 0.94 & 15.25 & Valid \\
\hline \multicolumn{5}{|c|}{ PU (Perceived Usefulness) } \\
\hline PU1 & There are features to display credit product options & 0.92 & 11.67 & Valid \\
\hline PU2 & Financial data and credit history for online financing is not necessary & 0.74 & 6.02 & Valid \\
\hline PU3 & The possibility of online financing to be approved is higher & 0.46 & 5.91 & Not Valid \\
\hline \multicolumn{5}{|c|}{ AB (Attitude toward Behavior) } \\
\hline $\mathrm{AB} 1$ & Online merchant financing is a wise way & 0.41 & 4.69 & Not Valid \\
\hline $\mathrm{AB} 2$ & Online merchant financing is the right alternative & 0.90 & 13.34 & Valid \\
\hline AB3 & Online merchant financing is a simple and practice way & 0.86 & 15.03 & Valid \\
\hline \multicolumn{5}{|c|}{ NB (Normative Belief) } \\
\hline NB1 & Other merchants recommend online financing & 0.89 & 20.79 & Valid \\
\hline NB2 & The merchant association recommends online financing & 0.89 & 26.66 & Valid \\
\hline NB3 & Parents/families suggest online financing & 0.87 & 21.19 & Valid \\
\hline \multicolumn{5}{|c|}{ SN (Subjective Norm) } \\
\hline SN1 & People who influence behavior convince me to apply for online financing & 0.53 & 6.72 & Valid \\
\hline SN2 & People who are important argue that I should apply for online financing & 0.86 & 19.63 & Valid \\
\hline SN3 & Information in the media directing me to apply for online financing & 0.65 & 10.05 & Valid \\
\hline \multicolumn{5}{|c|}{ SE (Self Efficacy) } \\
\hline SE1 & I have enough knowledge to apply online financing & 0.77 & 13.93 & Valid \\
\hline SE2 & I have fulfilled the criteria to apply for credit financing & 0.35 & 5.06 & Not Valid \\
\hline SE3 & I will feel comfortable applying for online financing & 0.89 & 10.21 & Valid \\
\hline \multicolumn{5}{|c|}{ FC (Facilitating Condition) } \\
\hline $\mathrm{FC} 1$ & The e-marketplace platform supports online financing practice & 0.67 & 12.92 & Valid \\
\hline $\mathrm{FC} 2$ & The e-marketplace is setting up facilities to enable the use of online financing & 0.96 & 14.35 & Valid \\
\hline FC3 & The e-marketplace platform ensures effective usage of online financing & 0.79 & 9.21 & Valid \\
\hline \multicolumn{5}{|c|}{ PBC (Perceived Behavior Control) } \\
\hline PBC1 & I am confident having the knowledge and the capacity to apply online financing & 0.57 & 11.92 & Valid \\
\hline PBC2 & I am capable of applying for online financing & 0.46 & 7.05 & Not Valid \\
\hline PBC3 & I can control all things relevant for applying for online financing & 0.69 & 8.21 & Valid \\
\hline \multicolumn{5}{|c|}{ MM (Marketing Mix) } \\
\hline MM1 & Customized credit package with the business type (product) & 0.69 & 11.48 & Valid \\
\hline MM2 & The interest rate in online financing is lower (price) & 0.24 & 3.01 & Not Valid \\
\hline MM3 & Simulation and comparison of credit package (promotion) & 0.78 & 11.36 & Valid \\
\hline MM4 & Online financing through e-marketplace is a suitable way to apply for credit (place) & 0.55 & 7.50 & Valid \\
\hline \multicolumn{5}{|c|}{ IOMF (Intention of Online Merchant Financing) } \\
\hline IOMF1 & I start utilizing the merchant feature in the e-marketplace website & 0.93 & 19.13 & Valid \\
\hline IOMF2 & I will look for online credit packages on the e-marketplace website & 0.93 & 18.84 & Valid \\
\hline IOMF3 & I'm going to start comparing online financing packages on the marketplace website & 0.96 & 19.50 & Valid \\
\hline IOMF4 & I'm soon / immediately applying for online financing through the marketplace website & 0.53 & 6,28 & Valid \\
\hline
\end{tabular}

* Standardized Loading Factors 
Table 2

The result of the questionnaire reliability test

\begin{tabular}{lccc}
\hline \multicolumn{1}{c}{ Latent Variables } & Cronbach's Alpha & Cut off Value & Remarks \\
\hline PU (Perceived of Usefulness) & 0.73 & $\geq 0.60$ & Reliable \\
PEOU (Perceived Ease of Use) & 0.82 & $\geq 0.60$ & Reliable \\
AB (Attitude toward Behavior) & 0.70 & $\geq 0.60$ & Reliable \\
NB (Normative Belief) & 0.93 & $\geq 0.60$ & Reliable \\
SN (Subjective Norm) & 0.78 & $\geq 0.60$ & Reliable \\
SE (Self Efficacy) & 0.72 & $\geq 0.60$ & Reliable \\
FC (Facilitating Condition) & 0.90 & $\geq 0.60$ & Reliable \\
PBC (Perceived Behavioral Control) & 0.83 & $\geq 0.60$ & Reliable \\
MM (Marketing Mix) & 0.77 & $\geq 0.60$ & Reliable \\
IOMF (Intention of Online Merchant Financing) & 0.80 & $\geq 0.60$ & Reliable \\
\hline
\end{tabular}

Table 3

The result of structural model test

\begin{tabular}{|c|c|c|c|c|c|}
\hline Endogen Variable & Eksogen Variable & Relationship & SLF* $^{*}$ & $t$-value & Hypothesis \\
\hline \multirow{4}{*}{$\begin{array}{l}\text { IOMF } \\
\text { (Intention of Online Merchant } \\
\text { Financing) }\end{array}$} & AB (Attitude toward Behavior) & $\mathrm{AB} \rightarrow \mathrm{ICO}$ & 0.23 & $3.49 * *$ & H1a Accepted \\
\hline & SN (Subjective Norm) & $\mathrm{SN} \rightarrow \mathrm{ICO}$ & 0.21 & $2.14 * *$ & H2a Accepted \\
\hline & PBC (Perceived Behavioral Control) & $\mathrm{PBC} \rightarrow \mathrm{ICO}$ & -0.02 & -0.21 & H3a Rejected \\
\hline & MM (Marketing Mix) & $\mathrm{MM} \rightarrow \mathrm{ICO}$ & 0.32 & $3.93 * *$ & H4 Accepted \\
\hline \multirow{3}{*}{$\begin{array}{l}\text { AB } \\
\text { (Attitude toward Behavior) }\end{array}$} & PEU (Perceived Ease of Use) & $\mathrm{PEOU} \rightarrow \mathrm{AB}$ & 0.32 & $3.33 * *$ & H1b Accepted \\
\hline & PU (Perceived Usefulness) & $\mathrm{PU} \rightarrow \mathrm{AB}$ & 0.33 & $3.43 * *$ & H1c Accepted \\
\hline & MM (Marketing Mix) & $\mathrm{MM} \rightarrow \mathrm{AB}$ & 0.03 & 0.39 & H1d Rejected \\
\hline \multirow{2}{*}{$\begin{array}{l}\text { SN } \\
\text { (Subjective Norm) }\end{array}$} & NB (Normative Belief) & $\mathrm{NB} \rightarrow \mathrm{SN}$ & 0.51 & $7.36^{* *}$ & H2b Accepted \\
\hline & MM (Marketing Mix) & $\mathrm{MM} \rightarrow \mathrm{SN}$ & 0.28 & $4.57 * *$ & H2c Accepted \\
\hline \multirow{3}{*}{$\begin{array}{l}\text { PBC } \\
\text { (Perceived Behavioral Control) }\end{array}$} & SE (Self Efficacy) & $\mathrm{SE} \rightarrow \mathrm{PBC}$ & 0.12 & 0.86 & H3b Rejected \\
\hline & FC (Facilitating Condition) & $\mathrm{FC} \rightarrow \mathrm{PBC}$ & 0.39 & $5.68 * *$ & H3c Accepted \\
\hline & MM (Marketing Mix) & $\mathrm{MM} \rightarrow \mathrm{PBC}$ & 0.42 & $7.08 * *$ & H3d Accepted \\
\hline
\end{tabular}

\section{* Standardized Loading Factors, ** Significant}

\section{Good of Fitness Test}

The result of the compatibility test of the whole model can be seen in Table 4. The model's comprehensive compatibility test produced a chi-square value of 283.86, with a p-value of 0.033. The measure of Good of Fitness (GOF) Test for $p$-value is $\geq 0.05$; therefore, we can conclude that the model has marginal compatibility; however, the chisquare statistical test is not the only basis for determining the suitability of the data with the model. Another compatibility test of the whole model (NCP, RFI, IFI, CFI, and PNFI) showed good results (good fit), which means that the hypothesized model fits the empirical data well.

Therefore, this model is suitable for an interpretation, as shown in SEM Figure 2.

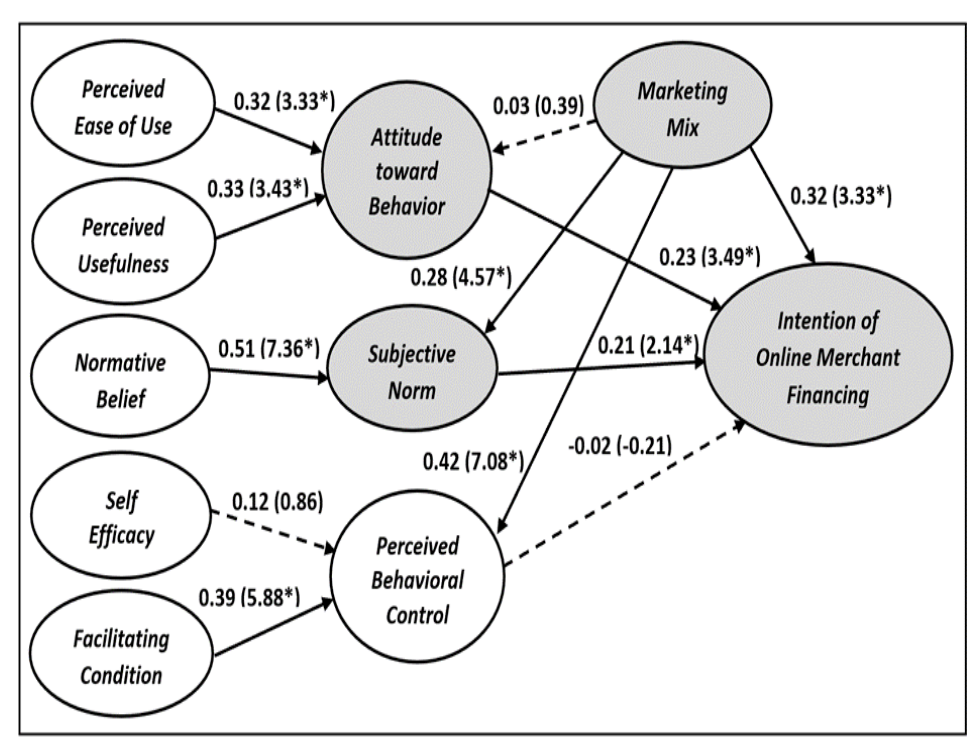

Figure 2. The Structural Equation Model Path Coefficients 
Table 4

The result of the compatibility test of the overall model (goodness of fit)

\begin{tabular}{|c|c|c|c|}
\hline GOF Tests & GOF Criteria & Value & Description \\
\hline \multicolumn{4}{|l|}{ Absolute Fit Measures } \\
\hline Chi Square & The smaller the better ( $p$-value $\geq 0.05)$ & $\begin{array}{c}283.86 \\
(p=0.033)\end{array}$ & Marginal fit \\
\hline $\mathrm{NCP}$ & The smaller the better & 41.86 & Good fit \\
\hline \multicolumn{4}{|l|}{ Incremental Fit Measures } \\
\hline RFI & $\mathrm{RFI} \geq 0.90$ good fit & 0.96 & Good fit \\
\hline IFI & IFI $\geq 0.90$ good fit & 1.00 & Good fit \\
\hline CFI & $\mathrm{CFI} \geq 0.90 \operatorname{good}$ fit & 1.00 & Good fit \\
\hline \multicolumn{4}{|c|}{ Parsimonious Fit Measures } \\
\hline PNFI & The bigger the better $(0 \geq$ PNFI $\geq 1)$ & 0.85 & Good fit \\
\hline
\end{tabular}

\section{Discussion}

\section{Structural Model Interpretation}

The path in Figure 2 shows that the marketing mix (MM) was the most dominant latent variable affecting intention with path coefficient 0.32 (Hypothesis 4 was proven). Consumers now require individual products (Heikkinen, 2018). Online merchants need tailored credit facilities (products) that fit with their business type, as producers or resellers. Moreover, the e-marketplace feature allows online merchants to compare several credit packages offered by each financial institution (promotion). Micro merchants will compare a digital financial service against other accessible options (Pulse Lab Jakarta, 2018). This study's results support the previous research of Aqrobaee et al. (2014), and Pour et al. (2013), where MM variables have a significant positive effect on intention (attracting customers).

The price indicator was the only element of the marketing mix that is not valid. The finding was consistent with the result of Reynolds et al. (2020) that a small-medium enterprises (SME) in the United States with a higher market orientation might have a higher level of adoption of technologies, despite being cost-conscious. D'Attoma and Ieva's (2020) research findings on enterprise-level manufacturing and service in Germany also show that introducing a change in the pricing strategy does not support successful innovation. Regarding Pulse Lab Jakarta (2018) and Hoppe et al. (2016) report that micro-merchants prefer convenience over cost (price). Banks usually require borrowers to have a credit history, collateral, or a permanent job. Online financing through e-marketplace (place) was more convenient for micro-merchants, as it does not require administrative requirements or collateral.
The study also tried to confirm the indirect relationship of the marketing mix (MM) perception on the intention of online merchant financing (IOMF), as a development of the Decomposed Theory of Planned Behavior (DTPB) model. This research tested the role of attitude (AB), subjective norm (SN), and perceived behavioral control (PBC) as the mediator between marketing mix perception and online financing intentions. The normative belief and marketing mix's effect on SN was positive and significant supporting Hypothesis $2 \mathrm{~b}$ (loading factor 0.51 ) and Hypothesis $2 \mathrm{c}$ (loading factor 0.28). The impact of $\mathrm{SN}$ on the intentions was significant and positively supported Hypothesis 2a with a path coefficient of 0.21 . Thus, the structural equation model path showed that only SN plays the role of the marketing mix mediation of online financing intentions via the e-marketplace platform.

All of the latent variable indicators of subjective norm and normative beliefs were valid. Online merchants or users signed up for a service to follow others' footsteps (merchants) in their neighborhood (Pulse Lab Jakarta 2018). Research by Maulana et al. (2018) and Aziz and Afaq (2018) had similar proof that indicated particular reference to the parents, siblings, peers, and colleagues (normative belief) was perceived as an essential referent group to affect clients' subjective norms to participate in Islamic banking. These findings were also consistent with the previous research of Aziz et al. (2017) of factors determining intentions towards the adoption of family takaful where antecedents of subjective norms were a word of mouth (normative belief) and mass media references (marketing mix). In a study on the plan for replacing Single-Occupant Vehicles with Urban Public Transport, Dolatabadi et al. (2012) have provided a significant positive effect of the social marketing mix on intentions, both directly and through normative beliefs. 
Among the three antecedents of attitude toward behavior $(\mathrm{AB})$ in this research, perceived ease of use (PEU) with loading factor 0.32 (Hypothesis $1 \mathrm{~b}$ approved) and perceived usefulness (PU) with loading factor 0.33 (Hypothesis 1c approved) were statistically significant. According to Davis (1989), this result shows that PU and PEU positively impact attitudes. In the scope of e-commerce, these results support the previous investigation by Baharun et al. (2015), Changchit et al. (2018), Gangwal and Bansal (2016), Reynolds et al. (2020), and Ye and Zhang (2014).

The third antecedent of attitude toward behavior (AB) was the marketing mix. This exogenous variable did not significantly affect the attitude, or Hypothesis 1d was not supported (t-value 0.39). The finding was partially in line with Sriram et al. (2019) that price intelligence (price) and delivery risk (place) do not affect attitude towards e-commerce websites' popularity. Pulse Lab Indonesia (2018) reports that most micro-merchants are reluctant to read information or advertise on digital financial services (promotion). They respond much better to specific use cases than product knowledge. PEU is the perceived effort required to learn and use the system, and PU is a user's belief that using a proper tool will enhance his job performance (Davis 1989). This finding is in line with the results of research by Ye and Zhang (2014), who examined whether and how sales promotion affects online buyers' purchasing intention in $\mathrm{C} 2 \mathrm{C}$ e-commerce transactions. The results suggest that sales promotion doesn't impact purchasing attitude and purchasing intention directly, but it influences PEU. Thus, PEU is a mediating variable, which in turn impacts purchasing intention. The research finding was different from prior studies where the marketing mix generally influences the attitude, as proven by Mbengo and Phiri (2015), and Mosavi (2012).

As an exogenous variable, the marketing mix had the most substantial influence on perceived behavioral control (PBC) of online merchant financing, with a path coefficient of 0.42 (Hypothesis $3 \mathrm{~d}$ proven). The results of previous research about the intention to choose a vehicle and social marketing mix also found that digital marketing (Dahiya \& Gayatri, 2017) and the social marketing mix (Dolatabadi et al., 2013) were significant determinants of PBC. However, the findings revealed that $\mathrm{PBC}$ did not affect the intention of the merchant $\mathrm{PBC}$ in determining intention financing (Hypothesis 3a rejected). These research findings were consistent with Aziz and Afaq (2018) and Bizri et al. (2017) results, who researched the intentions of adopting Islamic banking/finance in Pakistan and Lebanon. The conclusion also inlines with Kajenthiran et al. (2016), who examine youth's intention in the northern part of Sri Lanka in applying for microcredit to create a startup business. However, the findings of Tolba et al. (2016) provide contradictory results where PBC factors influence Egyptian MSME owners' intentions in taking commercial bank loans.

The finding of this study supported Hypothesis 3c, which reveals that facilitating condition (FC) positively and significantly affects the PBC (loading factor 0.39), but it did not automatically affect $\mathrm{PBC}$ toward financing intention (IOMF) since Hypothesis $3 \mathrm{~b}$ was not supported or self-efficacy (SE) has no significant influence on PBC (t-value 0.86). Online merchants' self-efficacy was not significant because we found that the level of confidence to use the online finance feature in the e-marketplace platform was still low. As is the case with accessibility for digital financial services users, micro-merchants need to trust their ability to use the technology to adopt them (Pulse Lab Jakarta, 2018). This finding did not support previous research where SE usually influenced PBC significantly (Gangwal \& Bansal, 2016, Husin \& Rahman, 2015; Kazemi et al., 2013; Maulana et al., 2018).

\section{Implications}

The intention model of online merchants in the e-marketplace provides several managerial implications for financial institutions. This research is the first to conduct a large-scale empirical investigation to measure marketing mix activity's effectiveness through e-marketplaces media. The study showed that the perception of the marketing mix (MM), attitude toward behavior (AB), and subjective norm (SN) has a significant effect on the intention of online merchant financing. Research findings described that online merchants did not perceive the marketing mix through attitude because they responded much better to specific use cases than the introduction to product knowledge. The financial institutions have been more focused on pricing, whereas, based on research findings, it was not an essential indicator of the marketing mix's perception (Sriram et al., 2019). Most financial institutions have not considered the online merchants' attitude as a strategic marketing factor.

The opposite findings showed that third parties (online merchant association, other online merchants, and family) were the prominent influencers (subjective norm) in online merchants' perception of the marketing mix. Financial institutions have started to approach through associations when implementing a marketing mix strategy. The online merchant association has a role in introducing the online business model to micro small and medium enterprises (MSMEs). As trusted peers, the association plays a position as an antecedent of the subjective norm.

In order to apply the results of research to make a matrix of a perceived marketing mix based on research finding, 
FGD (Focus Group Discussion) is conducted, involving nine practitioners from financial institutions (credit expert) consisting of three bank managers, three general manager of a leasing company and three directors of a fintech company (Marczak \& Sewell 2006). Representatives from e-marketplaces and online seller associations were also present in this discussion to provide an overview of the existing system. The FGD discussed how to apply the research findings by formulating the marketing mix strategy (product, promotion, price, and place) practically in the real market.

The marketing mix perception has a significant effect on the intention to apply for microcredit, both directly to online merchants and through third parties' perception (subjective norm). The study found that attitude toward behavior also affects the intention. However, most financial institutions have not considered the online merchants' attitude as a strategic marketing factor. The FGD (Focus Group Discussion) compiled a combination of marketing mix elements (product, promotion, price, and place) with independent variables (attitude towards behavior and subjective norm) that significantly influence the intention of online financing, as shown in the following matrix (Table 5).

Kannan and Li (2017) discussed how the Internet provides multiple new ways to reach customers and promote products. Unfortunately, most micro-merchants are reluctant to read information or advertising on digital financial services. They respond much better to specific use cases than the introduction to product knowledge, which they often find overwhelming. (Pulse Lab Jakarta, 2018). Therefore, financial institutions' cooperation with e-marketplaces needs to be enhanced. Promotions and place (platform) should display an interactive feature of credit products. The marketplace platform could demonstrate an easy online trial to apply for microcredit (perceived ease of use) and show an online comparison engine to compare and choose credit (perceived usefulness).

Table 5

Summary of managerial implications based on research findings

\begin{tabular}{|c|c|c|c|c|c|}
\hline \multirow{2}{*}{ Construct } & \multirow[t]{2}{*}{ Latent Variable/Indicators } & \multicolumn{4}{|c|}{ Managerial Implication } \\
\hline & & Product & Price & Promotion & Place (Platform) \\
\hline \multirow{2}{*}{$\begin{array}{l}\text { Attitude } \\
\text { Toward } \\
\text { Behavior }\end{array}$} & $\begin{array}{l}\text { Perceived Ease of Use/ } \\
\text { Easy Requirement }\end{array}$ & $\begin{array}{l}\text { Credit applica- } \\
\text { tion with simple } \\
\text { document } \\
\text { requirement }\end{array}$ & \multirow{2}{*}{$\begin{array}{l}\text { Interest rate is not } \\
\text { an issue, as long } \\
\text { as the system is } \\
\text { easier, faster, and } \\
\text { simpler than the } \\
\text { conventional way }\end{array}$} & $\begin{array}{l}\text { An easy online } \\
\text { trial to apply } \\
\text { for microcredit }\end{array}$ & $\begin{array}{l}\text { Credit application } \\
\text { features on an } \\
\text { easily accessible } \\
\text { online platform }\end{array}$ \\
\hline & $\begin{array}{l}\text { Perceived Usefulness/ } \\
\text { Feature of Creditor Option }\end{array}$ & $\begin{array}{l}\text { Credit with } \\
\text { choice options } \\
\text { that suit with } \\
\text { merchant's need }\end{array}$ & & $\begin{array}{l}\text { Online } \\
\text { comparison } \\
\text { engine to } \\
\text { compare and } \\
\text { choose credit }\end{array}$ & $\begin{array}{l}\text { Credit simulation } \\
\text { feature on the } \\
\text { platform to fit } \\
\text { suitable products }\end{array}$ \\
\hline \multirow{3}{*}{$\begin{array}{l}\text { Subjective } \\
\text { Norm }\end{array}$} & $\begin{array}{l}\text { Normative Belief/ } \\
\text { Association Influence }\end{array}$ & \multirow{3}{*}{$\begin{array}{l}\text { Customized } \\
\text { credit product } \\
\text { based on a re- } \\
\text { commendation } \\
\text { from influencers }\end{array}$} & \multirow{3}{*}{$\begin{array}{l}\text { Interest rate is not } \\
\text { an issue, as long } \\
\text { as the system is } \\
\text { easier, faster, and } \\
\text { simpler than the } \\
\text { conventional way }\end{array}$} & $\begin{array}{l}\text { Socialization or } \\
\text { training from } \\
\text { the association }\end{array}$ & $\begin{array}{l}\text { Seminar by } \\
\text { inviting } \\
\text { e-marketplaces } \\
\text { to instruct sign } \\
\text { up guidance for } \\
\text { online } \\
\text { applications }\end{array}$ \\
\hline & $\begin{array}{l}\text { Normative Belief/Other } \\
\text { Merchant influence }\end{array}$ & & & $\begin{array}{l}\text { Testimony from } \\
\text { a successful } \\
\text { merchant }\end{array}$ & $\begin{array}{l}\text { Approach agent of } \\
\text { financial } \\
\text { institutions to } \\
\text { socialize the }\end{array}$ \\
\hline & $\begin{array}{l}\text { Normative Belief/Family } \\
\text { Influence }\end{array}$ & & & $\begin{array}{l}\text { Review from } \\
\text { the millennial } \\
\text { generation }\end{array}$ & $\begin{array}{l}\text { online credit } \\
\text { applications } \\
\text { system through } \\
\text { e-marketplaces }\end{array}$ \\
\hline
\end{tabular}


Based on the most significant indicators on the exogenous attitude variable, the market considers microcredit applications with simple document requirements (perceived ease of use) and application with choice options that suit the merchant's need (perceived usefulness) as the right products. According to Wang and Kim (2018), in the e-commerce market, a strong store reputation and high service quality were crucial indicators for increasing browsers and sales amount. The price (interest rate) is not an issue, as long as the system is easier, faster, and simpler than the conventional way. Financial institutions can apply a flexible pricing policy as strategic price discrimination (Ighomereho \& Iriobe, 2019; McCarthy, 1960). They could charge a different interest rate for a credit product with a loose requirement or for one that has been customized. E-commerce benefits consumers in terms of price by facilitating price comparisons, and meanwhile, companies can gain a competitive advantage with pricing (Heikkinen, 2018).

In many markets, consumers make the leap from the physical to the online retail world in search of the cheapest deal. That is not the case in Southeast Asia, where digital shoppers are more likely to mention their experience (review) or the available choice than the price they paid (Hoppe et al., 2018). Therefore, credit packages (products) should be customized based on a recommendation from influencers, such as associations, other merchants, or families. D'Attoma and Ieva (2020) confirmed that the technological development and introduction of a new product could benefit from innovation in marketing to meet customers' changing needs.

Advertising through neighbors, family, or friends as the agent of financial institutions will be more effective. They are emotional mediators of technological change and behavior (Pulse Lab Jakarta 2018). Demographic data shows that respondents who had experience in applying for credit online reached $53.62 \%$. This data indicates that more than half of online merchants repurchase/reapply credit intentions. They have the capacity to become agents because they can provide reviews and testimonies about the benefits of online financing (promotion). The agents, user communities, or supporting partner firms' management practices could enhance leverage contingency (experimentation) toward innovation performance (Hussein \& Attia, 2019; Santoso et al., 2020). Promotion by providing application trial reviews from millennials and testimonials from successful merchants will increase the intention of applying for online credit.

Online seller associations have a role in introducing online businesses to micro small and medium enterprises (MSMEs) by providing seminars, training, and mentoring to an online businesses. MSMEs require fast and easy ac- cess to information regarding training and skills acquisition (Capri, 2018). As trusted peers, the association acts as the interface of a digital financial service to adopt them. For this reason, associations can act as intermediaries by inviting e-marketplaces to instruct sign up guidance for online applications. The concept is similar to Hossain's (2020) research, where private organizations' support plays a role as a moderation variable. Organizational support in terms of information and training for generating financial and non-financial growth of small firms in Bangladesh. The association also acts as an information channel (advertising) for financial institutions to disseminate online financing benefits for business development.

The harnessing of the digital technology economy, such as e-marketplace, has the potential to develop small enterprises to the digital global economy (Capri, 2018). With a large number of MSMEs, Indonesia has an opportunity to pioneer the development of new digital services, especially advanced mobile financial services and e-commerce. The governments/regulators need to work together with the associations, e-marketplaces, and financial institutions in designing policies and regulations. This policy will support the plan to use e-marketplaces as one of the media for channeling microcredit. Implementation regulations need to monitor and make sure the program demonstrates an improvement in MSMEs (Galli-Debicella, 2020).

\section{Conclusion and Future Research}

The current research results offer valuable insights for financial institutions and the government in microcredit distribution plans through e-commerce media. Online merchants' perceptions of the marketing mix are still limited to the promotion of financial institutions. The intention to apply for microcredit can be developed by establishing a subjective norm through associations, neighbors, family, or friends. They are emotional mediators of technological change and behavior (Pulse Lab Jakarta 2018). Academically, these findings contribute to broadening our understanding of intention in the context of marketing strategies. Using the Decomposed Theory of Planned Behavior (DTPB) model, the study's result showed that subjective norms play the role of marketing mix mediation of online financing intentions via the e-marketplace platform.

This research limitation is restricted in Indonesia-based entrepreneurs using APOI (Indonesian Online Sellers Association) members as initial research to obtain a general overview of online sellers in the e-marketplace. Further research involving the e-marketplace using an online merchant database can provide an accurate intention model with detailed information about the size and business model 
and types of selling goods or services. The study has not included field latent variables that might significantly influence the intention of reapplying, such as risk perception, credit system compatibility, and experience. The monitoring and research on actual behavior and level of satisfaction post-approval/disbursement of credit facilities needed to measure the potential for repurchase intention. Further research using the Unified Theory of Acceptance and Use of Technology (UTAUT) model will provide an overview of online merchants' actual behavior in applying for online microcredit application through e-marketplaces platform.

\section{Acknowledgment}

The authors would like to thank Indonesia Online Sellers Association (Asosiasi Pebisnis Online Indonesia/APOI) for data support in providing research respondent information. The author funded the research at his own expense and did not receive funding from any other funder.

\section{References}

Ajzen, I. (1991). The theory of planned behaviour. Organizational Behavior and Human Decision Processes, 50,(2), 179-211.

Aqrobaee, N., Amirkabiri, A., \& Evanaki, M. (2014). Factors influencing the preferred choice of customers in bank (Case study Bank Mehr Eqtesad). Journal of Current Research in Science, 2(6), 943-956.

Al-Mamary, Y. H., Al-Nashmi, M., Hassan, Y. A., \& Shamsuddin, A. (2016). A critical review of models and theories in field of individual acceptance of technology. International Journal of Hybrid Information Technology, 9(6), 143-158.

Aziz, S., \& Afaq, Z. (2018). Adoption of Islamic banking in Pakistan unempirical investigation. Cogent Business \& Management, 5, 1-18.

Aziz, S., Husin, M., \& Hussin, N. (2017). Conceptual framework of factors determining intentions towards the adoption of family takaful- An extension of decomposed theory of planned behaviour. International Journal of Organizational Leadership, 6, 385-399.

Baharun, R., Mirghasemi, F., Rahman, N., \& Awang, Z. (2015). Aplication of decomposed theory of planned behavior on post graduated student toward online shoping. Jurnal Kemanusiaan, 13(1), 30-41.

Baltes, L. (2016). Digital marketing mix specific to the IT Field. Bulletin of Transilvania University of Braşov. Series V: Economic Sciences, 9(1), 33-44.

Bank Indonesia. (2015). Profil Bisnis Usaha Mikro, Kecil dan Menengah. Jakarta: BI Publisher.
Bizri, R., Jardali, R., \& Bizri, M. (2017, October 12). Financing family firms in the Middle East: The choice between Islamic and conventional finance. International Journal of Entrepreneurial Behavior \& Research, 24(4), 842-865. doi:10.1108/IJEBR-10-2016-0349

Capri, A. (2018). Micro and small businesses in Indonesia's digital economy. Asia Pacific Foundation of Canada. https://apfcanada-msme.ca/sites/default/files/2019-03/ Micro\%20and\%20Small\%20Businesses\%20in\%20 Indonesia\%E2\%80\%99s\%20Digital\%20Economy.pdf

Changchit, C., Cutshall, R., Lonkan, R., \& Pongwiritthon, R. (2018). Determinants of Online Shopping Influencing Thai. Journal of Internet Commerce, 18(1), 1-23. doi:10.1080/15332861.2018.1496391

Corrot, P., \& Nussenbaum, A. (2014, March). Marketplace: The future of e-commerce. Mirakl Marketplace Platform C. https://www.mirakl.com/data/uploads/ White-paper-Marketplace.pdf

Dachyar, M., \& Banjarnahor, L. (2017). Factors influencing purchase intention towards. Intangible Capital, 13(5), 946-968.

Dahiya, R., \& Gayatri. (2017). Investigating Indian car buyers' decision to use digital marketing communication: An empirical application of decomposed TPB. Vision: The Journal of Business Perspective, 21(4), 385-396.

Das, K., Tamhane, T., Vatterott, B. Wibowo, P., Wintels, S. (2018). The digital archipelago: How online commerce isdriving Indonesia's economic development. McKinsey \& Company. https://www.mckinsey.com/ / media/McKinsey/eatured\%20Insights/Asia\%20Pacific/The $\% 20$ digital $\% 20$ archipelago $\% 20$ How $\% 20$ online $\% 20$ commerce $\% 20$ is $\% 20$ driving $\%$

D’Attoma, I., \& Ieva, M. (2020). Determinants of technological innovation success and failure: Does marketing innovation matter? Industrial Marketing Management, 91, 64-81.

Davis, F. (1989). Perceived usefulness, perceived ease of use, and user acceptance of information technology. MIS Quarterly, 13(3), 319-340.

Dolatabadi, H., Parhizgar, M., \& Aghcheh, M. (2013). The impact analysis of social marketing mix on the intention of replacing single-occupant vehicles with urban public transport. International Journal of Academic Research in Business and Social Sciences, 3(4), 60-71.

Ennew, C., \& Waite, N. (2007). Financial services marketing- An international guide to principles and practice. Butterworth-Heinemann.

Fishbein, M., \& Ajzen, I. (1975). Belief, attitude, intention, and behavior: an introduction to theory and research. Addison-Wesley Publishing Company.

Galli-Debicella, A. (2020). The efficacy of SBA loans on 
small firm survival rates. Journal of Small Business Strategy, 30(2), 26-34.

Gangwal, N., \& Bansal, V. (2016). Application of decomposed theory of planned behavior for m-commerce adoption in India. In S. Hammoudi, L. Maciaszek, M. M. Missikoff, O. Camo, \& J. Cordeiro (Eds.), Proceedings of 18th International Conference on Enterprise Information System (ICEIS) Vol 2. (pp. 357-367). SCITEPRESS - Science and Technology Publications, Lda.

Hartoyo, H., Karambut, F., Nurmalina, R., \& Najib, M. (2019). The intention in online submission of micro credit. European Research Studies Journal, 3(22), 186-200.

Heikkinen, T. (2018). Marketing mix in E-commerce. [Thesis]. Aalto University School of Business.

Hoppe, F., Lamy, S., \& Canna, A. (2016). Can Southeast Asia live up to its E-commerce potential? Bain \& Company, Inc. http://www2.bain.com/Images/BAIN_ BRIEF_Can_Southeast_Asia_Live_Up_to_Ecommerce_potential.pdf

Hossain, M. M. (2020). Financial resources, financial literacy and small firm growth: Does private organizations matter? Journal of Small Business Stategy, 30(02), 3558.

Husin, M., \& Rahman, A. (2015). Predicting intention to participate in familiy takaful scheme using Decomposed Theory of Planned Behavior. International Journal of Social Economics, 43(12), 1351-1366.

Hussein, R. S., \& Attia, M. (2019). Mobile internet use by Generation Z: Evidence form an emerging market. Academy of Marketing Studies Journal, 23(4), 1-16.

Ighomereho, S. O., \& Iriobe, O. C. (2019). E-marketing in Nigeria: Benefits, challenges and strategies. 9(2), 220234.

Indonesian Government. (2015). Pedoman Pelaksanaan Kredit Usaha Rakyat. Regulation of the Coordinator Minister for the Economy of the Republic of Indonesia No. 6.

Indonesian Government. (2017). Peta jalan sistem perdagangan nasional berbasis elektronik (road map E-commerce) Tahun 2017 - 2019. Peraturan Presiden Republik Indonesia No. 74 Tahun 2017.

ING Bank. (2016, October 7). FinTech for micro, small and medium sizes enterprises. https://www.ing.nl/media/ ING_EBZ_FinTech-for-MSMEs_tcm162-111437.pdf

Kajenthiran, K., Achchuthan, S., \& Karunanithy, M. (2016, July). Antecedents of youth's intentions in seeking microcredit: Evidence from Jaffna district, Sri Lanka. International Journal of Accounting \& Business Finance 1, 78-99.
Kannan, P., \& Li, H. (2017). Digital marketing: A framework, review and research agenda. International Journal of Research in Marketing, 34(1), 22-45.

Karambut, F., Hartoyo, H., Nurmalina, R., \& Najib, M. (2019). Determinants of online sellers intention in to apply micro credit. Asian Journal of Business and Management, 7(2), 35-45.

Kazemi, A., Nilipour, A., Kabiry, N., \& Hoseini, M. (2013). Factors affecting Isfahanian mobile banking adoption based on the decomposed theory of planned behavior. International Journal of Academic Research in Business and Social Sciences, 3(7), 230-245.

Kotler, P., \& Armstrong, G. (2012). Principle of marketing. Prentice Hall.

Kotler, P., \& Keller, K. (2016). Marketing management (global edition) 15th edition. Pearson Education Limited.

Lai, P. (2017). The literature review of technology adoption model and theories for the novelty of. Journal of Information Systems and Technology Management, 14(1), 21-38.

Marczak, M., \& Sewell, M. (2006). Using focus groups for evaluation. The University of Arizona. https://cals.arizona.edu/sfcs/cyfernet/cyfar/focus.htm

Maulana, H., Razak, D., \& Adeyemi, A. (2018). Factors influencing behavior to participate in Islamic microfinance. International Journal of Islamic and Middle Eastern Finance and Management, 11(1), 109-130.

Mbengo, P., \& Phiri, M. (2015). Mobile banking adoption: A rural Zimbabwean marketing respective. Corporate Ownership \& Control, 13(1), 195-204.

McCarthy, E. J. (1960). Basic marketing: A managerial approach (6 ed.). Richard D. Irwin, Inc.

McKinsey \& Company. (2018). The digital archipelago: How online commerce is. https:/www.mckinsey.com/ /media/McKinsey/eatured\%20Insights/ Asia $\% 20$ Pacific/The $\% 20$ digital $\% 20$ archipelago $\% 20$ How $\% 20$ online $\% 20$ commerce $\% 20$ is $\% 20$ driving $\% 20$ Indonesias\%20economic\%20development/The-digital-archipelago-Executive-summary.ashx.

Momani, A., \& Jamous, M. (2017). The evolution of technology acceptance theories. International Journal of Contemporary Computer Research, 1(1), 51-58.

Mosavi, S., Kaveh, M., \& Ghaedi, M. (2012). Behavioral intention in internet shopping. African Journal of Business Management, 6(4), 1515-1526. doi:10.5897/ AJBM11.2331

Pogorelova, E., Yakhneeva, I., Agafonova, A., \& Prokubovskaya, A. (2016). Marketing mix for E-commerce. International Journal of Environmental \& Science Education, 11(14), 6744-6759. 
Pour, B. S., Nazari, K., \& Emami, M. (2013, 09 14). The effect of marketing mix in attracting customers: Case study of Saderat Bank in Kermanshah Province. African Journal of Business Management, 7(34), 32723280 .

Pulse Lab Jakarta. (2018, September). Banking on fintech : Financial inclusion for micro enterprises in Indonesia. https://issuu.com/pulselabjakarta/docs/final_report_-_ banking_on_fintech

Reynolds, S., Cotrino, F., Ifedi, C., \& Donthu, N. (2020). An exploratory study of executive factors that lead to technology adoption in small business. Journal of Small Business Strategy, 30(2), 1-16.

Santoso, A. S., Prijadi, R., \& Balqiah, T. E. (2020). How open innovation strategy and effectuation within platform ecosystem can foster innovation performance: Evidence from digital multi-sided platform startups. Journal of Small Business Strategy, 30(3), 102-126.

Sriram, K., Phouzder, K., Mathew, A. O., \& Hungund, S. (2019). Does e-marketing mix influence brand loyalty and popularity of e-commerce websites? ABAC Journal, 39(2), 64-81.

Sulaiman, Y., Yusr, M., \& Ismail, K. (2017). The influence of marketing mix and perceived risk factors on online purchase intentions. International Journal of Research in Business Studies and Management, 4(9), 30-40.

Taylor, S., \& Todd, P. (1995). Understanding information technology usage: A test of competing models. Information Systems Research, 6(2), 144-176. doi:10.1287/ isre.6.2.144

Tolba, A., Seoudi, I., \& Fahmy, K. (2016). Factors influencing intentions of Egyptian MSME owners in taking commercial bank loans. Journal of Small Business \& Entrepreneurship, 27(6), 497-518. doi:10.1080/08276 331.2015 .1102478

Wang, Z., \& Kim, Y. (2018). How marketing factors influence online browsing and sales: Evidence from China's e-commerce market. 34(2), 253-264.

Ye, L. R., \& Zhang, H. (2014). Sales promotion and purchasing intention: Applying the technology acceptance model in consumer-to-consumer marketplaces. International Journal of Business, Humanities and Technology, 4(3), 1-5. 